\title{
The hyper-reactive malarial splenomegaly: a systematic review of the literature
}

\author{
Stefania Leoni ${ }^{1,2}$, Dora Buonfrate ${ }^{1}$, Andrea Angheben ${ }^{1}$, Federico Gobbi ${ }^{1}$ and Zeno Bisoffi ${ }^{*}$
}

\begin{abstract}
Background: The hyper-reactive malarial splenomegaly syndrome (HMS) is a leading cause of massive splenomegaly in malaria-endemic countries. HMS is caused by a chronic antigenic stimulation derived from the malaria parasite. Classic Fakunle's major criteria for case definition are: persistent gross splenomegaly, elevated anti-malarial antibodies, IgM titre >2 SD above the local mean value and favourable response to long-term malaria prophylaxis. The syndrome is fatal if left untreated. The aim of this study is to systematically review the literature about HMS, particularly focussing on case definition, epidemiology and management.

Methods: The search strategy was based on the following database sources: Pubmed, EmBase, Scopus. Search was done in March, 2014 and limited to English, Spanish, Italian, French, and Portuguese.

Results: Papers detected were 149, of which 89 were included. Splenomegaly was variably defined and the criterion of increased lgM was not always respected. The highest prevalence was reported in Papua New Guinea (up to 80\%). In different African countries, 31 to $76 \%$ of all splenomegalies were caused by HMS. Fatality rate reached 36\% in three years. The most frequent anti-malarial treatments administered were weekly chloroquine or daily proguanil from a minimum of one month to lifelong. In non-endemic countries, a few authors opted for a single, short anti-malarial treatment. All treated patients with no further exposure improved. Cases not completely fulfilling Fakunle's criteria and therefore untreated, subsequently evolved into HMS. It seems thus appropriate to treat incomplete or 'early' HMS, too.

Conclusions: For patients not re-exposed to endemic areas, a short course of treatment is sufficient, showing that eradicating the infection is sufficient to cure HMS. Longer (probably lifelong) courses, or intermittent treatments, are required for those who remain exposed. Splenectomy, associated with high mortality, should be strictly limited to cases not responding to medical treatment.
\end{abstract}

Keywords: Hyper-reactive, Malarial, Splenomegaly, Management, Treatment, Epidemiology, Review

\section{Background}

Hyper-reactive malarial splenomegaly (HMS) represents one of the leading causes of massive splenomegaly in malaria-endemic countries [1]. HMS is caused by an aberrant immune response to a chronic antigenic stimulation in subjects long exposed to malaria parasites [2]. Previously defined as tropical splenomegaly syndrome (TSS), HMS has long been considered distinct from a splenomegaly directly resulting from malarial parasitaemia. The syndrome is characterized by macroglobulinaemia with overproduction of immunoglobulin, especially of the IgM class, which aggregate into high molecular

\footnotetext{
* Correspondence: zeno.bisoffi@sacrocuore.it

'Centre for Tropical Diseases, S Cuore Hospital, 37024, Negrar Verona, Italy

Full list of author information is available at the end of the article
}

immune complexes and cause persistent splenomegaly because of prolonged clearance from the reticuloendothelial tissue [3]. Cryoglobulins and autoantibodies, such as, for instance, rheumatoid factor, contribute to the macroglobulinaemia [4]. A direct correlation between the spleen size and the IgM titre has been described [5-8]. Genetic factors are likely to be involved in the development of HMS. Studies carried out in Papua New Guinea reported a higher incidence in individuals with HLA-DR2 haplotype or with HLA heterozygosity $[9,10]$. Moreover a retrospective study carried out in Ghana evidenced that the relatives of patients with HMS were more likely to have splenomegaly than population controls [11].

Diagnostic criteria for HMS were proposed by Fakunle in 1981 [12]. Major criteria are: persistent gross splenomegaly 
extending more than $10 \mathrm{~cm}$ below the costal margin, without any other apparent cause, elevated anti-malarial antibodies, IgM titre $>2$ standard deviations (SD) above the local mean value and favourable clinical and immunological response to long-term malaria prophylaxis [13]. Minor diagnostic criteria are: hepatic sinusoidal lymphocytosis, normal cellular and humoral immune responses to antigenic challenge, including phytohaemagglutinin stimulation (PHA), hypersplenism, lymphocyte proliferation, occurrence within families or tribes.

Other laboratory findings are related to hypersplenism, such as variable degrees of pancytopaenia, especially anaemia. The underlying mechanism causing anaemia is the plasma volume expansion and the spleen sequestration along with an increased haemolysis. Reticulocytes and indirect bilirubin are often increased [14,15]. Acute episodes of haemolysis can also occur and seem to be associated with an autoimmune, cold-agglutinin-mediated response triggered by non-patent parasitaemia [16]. Sinusoidal lymphocytosis may be revealed by histologic examination of liver biopsy, but it is not specific. The peripheral blood smear in HMS subjects is most often negative. However, using more sensitive diagnostic methods, such as polymerase chain reaction (PCR), the proportion of positive cases increases [17-19].

The main, severe complications of HMS are acute infectious illnesses, haemolytic anaemia (especially during pregnancy) and splenic rupture. According to historical data, the syndrome is often fatal if left untreated [20].

Some authors have hypothesized that HMS could be considered as a pre-malignant state that could evolve to chronic lymphocytic or hairy cell leukaemia or splenic lymphoma with villous lymphocytes, as a result of a multi-step process with a single clone selection in a set of deregulated polyclonal expansion of lymphocytes [21-23]. Actually, HMS and lymphoproliferative disorders are often clinically indistinguishable. Serological similarities between HMS and splenic lymphoma with villous lymphocytes (SLVL) have also been reported. In the latter condition, too, a markedly raised antimalarial antibody and IgM level have been observed [24]. Spleen reduction after a prolonged anti-malarial treatment is one of the main criteria used to diagnose HMS. Failure to respond makes an alternative diagnosis more likely [25].

Despite a comparatively large amount of literature on malaria, only a few papers deal with this particular complication. Moreover, diagnostic criteria are not uniform, epidemiological data are scarce and the clinical management has been variable. This aim of this review was to retrieve the relevant literature on HMS, focusing in particular on three key aspects: diagnostic criteria for the case definition, epidemiology (prevalence and mortality) and management.

\section{Methods}

\section{Searching}

The search strategy was based on the following database sources: Pubmed, EmBase, Scopus, with no limitation as for the year of publication. The oldest paper retrieved was published in 1966. Our searching strategy was based on these keywords (using of course the specific language of each database): asymptomatic malaria, chronic malaria, malarious splenomegaly, splenomegaly syndrome, splenomegalic syndrome, tropical splenomegaly, malarial splenomegaly. Additional search terms used were: epidemiology, prevalence, incidence, pathogenesis, diagnosis, case definition, prognosis, mortality, fatality, management, treatment.

The search was restricted to 'humans' and to the following languages: English, French, Spanish, Italian, and Portuguese. The search was carried out in March 2014. Reference lists of all the articles identified were also examined and relevant cited references were reviewed similarly.

\section{Types of study}

Surveys, epidemiological studies, case reports/series, studies on etiology, pathogenesis, diagnosis and treatment of HMS were collected. Reviews were excluded from the analysis.

\section{Inclusion criteria}

Articles had to deal with hyperactive malaria splenomegaly or its synonymous, such as tropical splenomegaly or chronic malaria, as a main subject.

\section{Exclusion criteria}

Papers were excluded when primarily dealing with acute malaria or with other causes of splenomegaly (such as EBV, CMV, HIV, schistosomiasis). All papers identified were assessed by two reviewers (SL and DB) who independently screened the titles and abstracts, using the criteria mentioned above. Then they read the full text of those retained after the first screening. In case of differences, a final consensus was reached after discussion that included a third reviewer (ZB).

Data were extracted from all finally retained papers and specific fields of an Excel spreadsheet were populated. The spreadsheet was previously created on the basis of the study's purpose. With available data the analysis was focused first on epidemiology, such as gender and age of patients, country where the study was conducted and country of origin of the patients, prevalence of the syndrome in a given area, mortality rate, etc. Then we filled the section on diagnostic criteria and in particular if they followed the Fakunle's criteria or not. Finally data were extracted considering the type and duration of the treatment and when available, also data on outcome at follow-up. Finally, the reported treatment 
outcome of studies with more than 10 recruited subjects was summarized. The studies were obviously heterogeneous but, because of the extreme poverty of papers dealing with HMS, it was aimed to provide the most comprehensive picture of the main reported aspects of the syndrome since the first publication until now.

\section{Results}

The electronic search identified 331 papers from Pubmed, 60 From EmBase and 75 from Scopus. Sixtyeight duplicates were discarded. After an evaluation of language, titles and abstracts, a total of 152 papers were detected that may relate to this review. Thirteen were not retrieved. On the basis of the full text, 51 papers were discarded since they did not deal with HMS.

The remaining 89 papers were included. The flow is summarized in Figure 1 (PRISMA flow chart).
Sixty-three papers described cases observed or studies conducted in endemic areas. In particular, 50/63 (80\%) in Africa, 8/63 (12\%) in Asia [26-33], and 5/63 (8\%) in South America [16,34-37]. Of the 26 papers from nonendemic countries, 22 (85\%) concerned patients observed in Europe, the others were case reports from Israel [38], the USA [39,40] and Hong Kong [41]. Apart from two retrospective studies $[42,43]$ and one prospective longitudinal study [19], the other papers were case reports/case series. These included immigrants (15 papers), expatriates (ten papers) or both groups (one paper). The range of age of subjects under study fell from birth [44] to a maximum of 77 years [45] and most of the patients with HMS were young adults. According to some studies a male gender prevalence was noted but analysing the literature no significant gender difference was observed.

\section{PXIS M \\ PRISMA 2009 Flow Diagram}

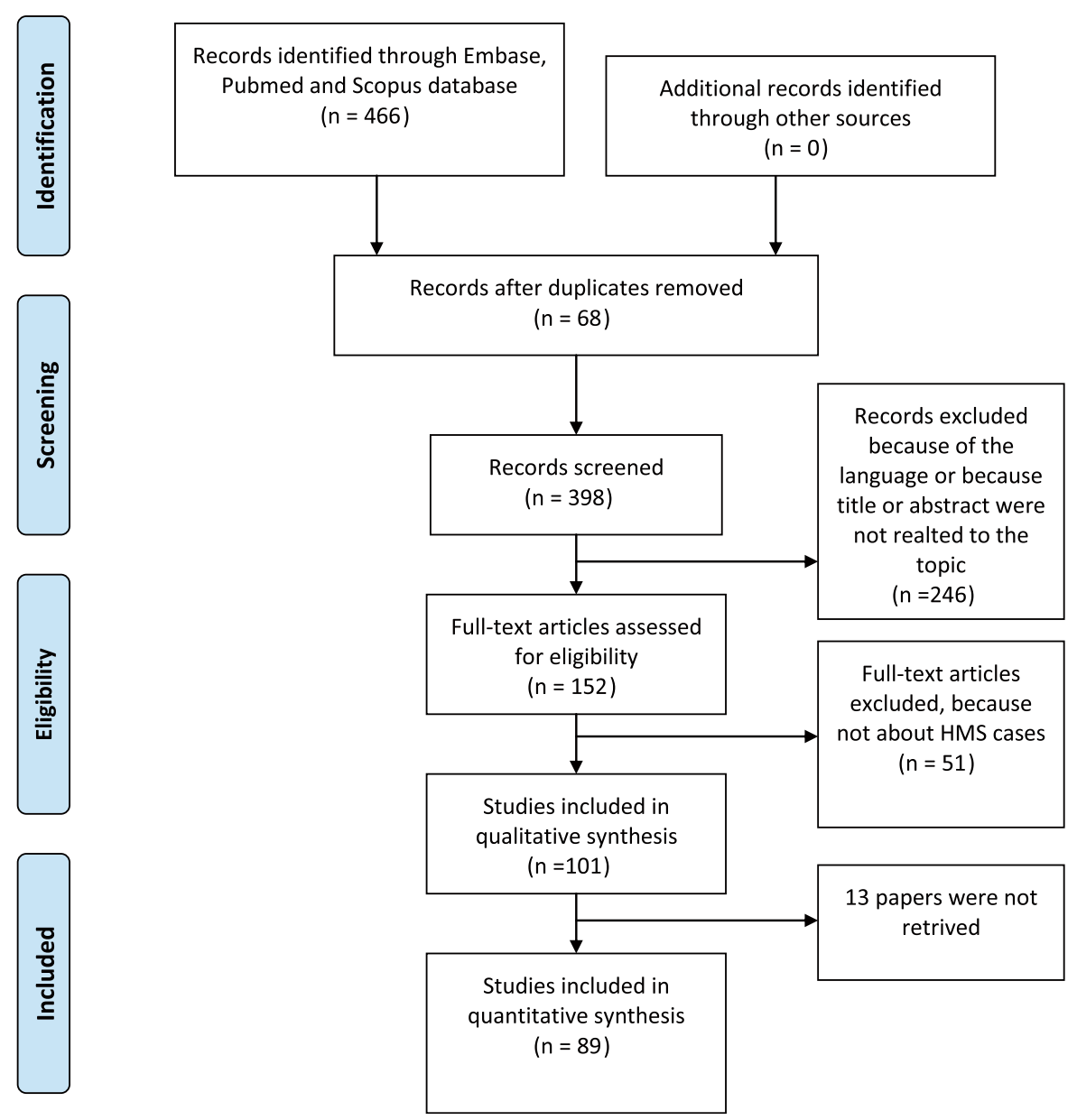

Figure 1 PRISMA flow chart. 


\section{Diagnostic criteria for case definition}

Fakunle's criteria were mostly used, but adherence to them was variable. Most authors declaring to follow Fakunle's criteria considered as splenomegalic a patient with spleen size bigger than $10 \mathrm{~cm}$ below the costal margin (Figure 2), but lower measures were also reported $[34,46]$. Overall, the range of the spleen size reported to define splenomegaly was extremely variable, from 3 [27] to $30 \mathrm{~cm}$ [47] below the costal margin. Both palpatory and echographic methods were used. Some authors preferred to use Hackett's spleen size classification $[16,20,29,35,48-50]$, which is based on palpation. They considered as splenomegalic a patient with spleen size classified at least in the II or III grade (Table 1). Other authors did not define splenomegaly, but described the spleen as "gross" [13] or "huge" [39]. The increase in IgM titre was not always respected. Some authors considered it neither specific nor necessary $[51,52]$. In five studies the syndrome was also diagnosed in absence of raised IgM [1,32,37,52,53].

In other studies the case definition relied on at least two out of the three major criteria (leaving aside anti-malarial antibody titre that is invariably raised), besides excluding other causes of splenomegaly $[28,42,43,54]$. It was observed that some of those patients, if further exposed to malaria, evolved to the complete syndrome, and this suggested the possibility to make the diagnosis at an early stage [43]. Moreover, a direct correlation between the splenomegaly class and the IgM level has been demonstrated, suggesting a continuum in the syndrome evolution [42].

Another approach to the diagnosis of HMS was a combination of major and minor criteria. In 1976, before the publication of Fakunle's criteria, Mardsen and Crane had suggested the following: persistent splenomegaly, hepatic sinusoidal lymphocytosis, disproportionate elevation of serum IgM levels and high anti-malarial antibody titre, without considering the response to the therapy [55]. In other papers, the exclusion of other causes of splenomegaly in an endemic area was sufficient to consider a patient as affected by HMS [56,57].

\section{Epidemiology in endemic countries}

There are scanty data regarding the prevalence of the syndrome in the general population. Studies performed in Papua New Guinea reported an extraordinarily high prevalence of the syndrome (85\% in five years old children and $80 \%$ in adults) among inhabitants of the Upper Watut Valley [58]. The relationship between the parasite rate and the spleen size varied with age: in children the spleen size appeared to be directly related to the parasite rate, while in adults the opposite occurred [44].

Studies conducted in The Gambia reported a much lower prevalence: 1.6 per 1,000 subjects aged ten years or older [44,59]. Other authors studied the proportion of splenomegaly caused by HMS. In northern Nigeria, 30 splenomegalic patients out of 75 (40\%) were classified as having HMS, and so were 137 out of 334 subjects in northern Zambia (again, 40\%), 38 patients out of 131 (31\%) in Kenya, 91/221 (41\%) in Ghana and 87/114 (76\%) in eastern Sudan [1,48,60-62].

In Papua New Guinea, the overall mortality rate in a series of 75 untreated patients during a 72-month period was $36 \%$, reaching $57 \%$ in patients with grade $\mathrm{V}$ splenomegaly [20]. In another study, the reported mortality

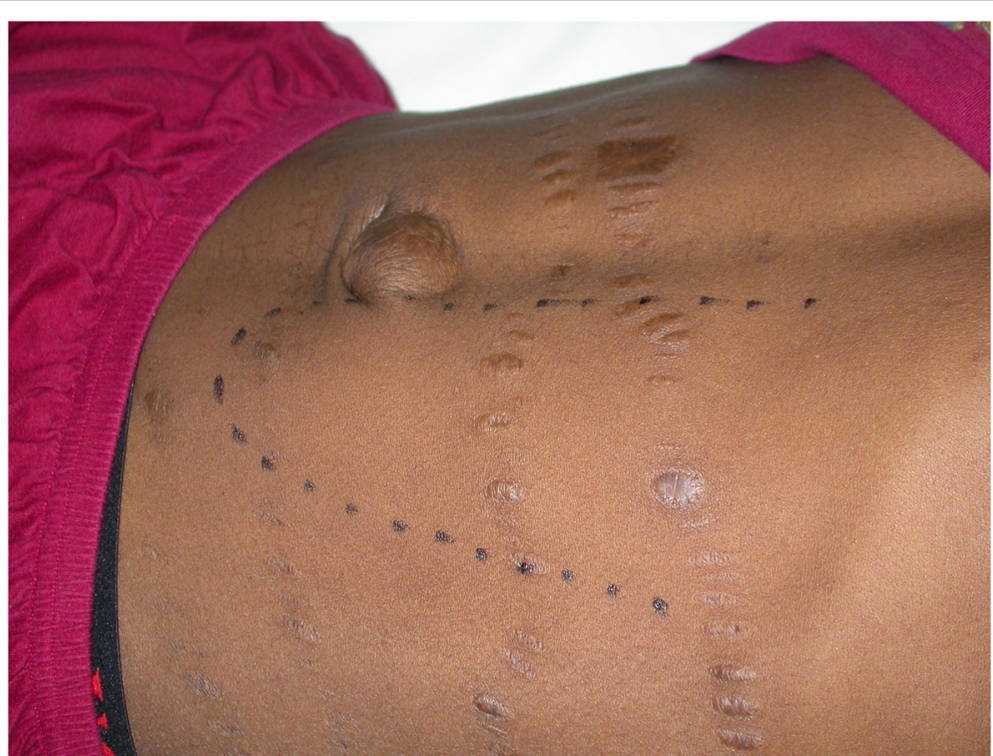

Figure 2 African patient with splenomegaly seen at the Centre for Tropical Diseases, Negrar 
Table 1 Hackett's spleen size classification

\begin{tabular}{ll}
\hline Spleen grade & Description of the spleen grade \\
\hline 0. & Spleen not palpable even on deep inspiration. \\
I. & $\begin{array}{l}\text { Spleen palpable below costal margin, usually on } \\
\text { deep inspiration. }\end{array}$ \\
II. & $\begin{array}{l}\text { Spleen palpable, but not beyond a horizontal line halfway } \\
\text { between the costal margin and umbilicus, measured in a } \\
\text { line dropped vertically from the left nipple. }\end{array}$ \\
IV. & $\begin{array}{l}\text { Spleen palpable more than halfway to umbilicus, but } \\
\text { n. }\end{array}$ \\
\hline
\end{tabular}

rate in adults was $26 \%$ at ten years follow-up, but it fell to $13 \%$ in subjects under chloroquine prophylaxis [2]. The main causes of death were infectious diseases, acute haemolysis and multi-organ failure (MOF) $[35,63,64]$.

\section{Non-endemic countries}

The first case of HMS in a Caucasian who lived in Africa was described in 1970 [65]. Only two case series were retrieved describing more than ten expatriates returning to Europe [42,43]. Most patients had lived for at least five years in an endemic area. Both series (in Belgium and Italy, respectively) included patients fully responding to the classic criteria (17/49 and 29/57, respectively) and patients with an incomplete syndrome. The clinical outcome at follow-up was favourable for all patients who remained in Europe and presented at follow-up. The only other case series described in Europe is a prospective study in Spain [19] on 14 immigrants (from Equatorial Guinea or Cameroon), all responded to Fakunle's criteria. Four had a positive blood film, and four additional patients were positive at PCR.

A six years old child was the youngest immigrant from Africa diagnosed with HMS [66]. A seven years old child, born in UK to Ghanaian parents, was diagnosed with HMS after three short trips to Ghana (eight weeks in total), the last one eight months before presentation. Despite the absence of fever or fever history, Plasmodium falciparum trophozoites and gametocytes were found in her blood [67].

\section{Therapy in endemic countries}

The most frequent anti-malarial treatments administered in endemic countries were weekly chloroquine $[2,26,31-34,37,49,61,62,68-71]$ or daily proguanil $[13,25$, $52,57,60,64,71-78]$. Other regimens were chloroquine plus primaquine $[27,70]$, mefloquine [28], quinine [18], pyrimethamine [56], artemether [18], and sulphadoxine/ pyrimethamine $[18,50]$. Overall, the duration of therapy ranged from a minimum of one month $[13,56]$ to a lifelong treatment [2]. The largest cohort of patients (148) under lifelong chloroquine prophylaxis showed an improvement of all, with a partial regression of splenomegaly and an increase of haemoglobin level over a period of 1218 months. However, in no case a normalization of the spleen size was observed. The prophylactic regimen halved the mortality rate over ten years compared to untreated patients [79]. Other studies confirmed the efficacy of this regimen [27,31,71]. The most recent one was carried out in Sudan in 2013 and reported, after a three-month therapy, a complete normalization of the spleen size in 14 patients out of 21 [69]. In Nigeria, 10/39 subjects fully recovered and 29/39 improved after daily proguanil administered for two to 12 months [76].

Two papers reported improvement after a single, short course of anti-malarial treatment followed by oral steroid therapy $[50,80]$. However, other authors observed that the syndrome tended to quickly relapse once antimalarial therapy was stopped [75,78]. Only one study in Sudan [18] opted (for the 33 patients included) for a short course anti-malarial treatment (various regimens) as for an acute falciparum malaria. For most of the patients, other treatments were administered during the follow-up (for 15 to 24 months). However, no prophylaxis was administered during the different treatments. Thirty-six patients had improved and 12 had worsened at the end of the follow-up period, while six were reported as unchanged. Table 2 summarizes the main results of the studies including more than ten patients.

Only few data are available on HMS treatment in pregnancy. A recent retrospective study carried out in Thailand reported the efficacy of weekly mefloquine, administered for two to 25 weeks (median nine weeks) to 31 pregnant women with suspected HMS, without any major adverse event. Those presenting only one or two major criteria of the conventional definition of HMS were also treated and showed on average a spleen size reduction of more than $40 \%$ [28].

\section{Therapy in non-endemic countries}

The management of HMS in non-endemic areas has been heterogeneous. Overall, the drugs used were: chloroquine, quinine plus clindamycin or doxycycline or pyrimethamine-sulphadoxine, proguanil, mefloquine, atovaquone-proguanil, halofantrine, and artemisinin derivatives. A few authors preferred to prescribe a short course ( $\leq$ seven days) of anti-malarial treatment, while the majority opted for longer therapy. Overall, the follow-up period ranged from six weeks to 36 months. In six studies out of 21 a short course of treatment (as for an acute malaria episode) was administered $[17,42,43,66,81,82]$. In the Belgian study (Table 3) [42] all 49 expatriates received a short course of antimalarial therapy. Thirty-nine patients were followed up for at least two weeks after treatment (median six 
Table 2 Treatment outcome: studies conducted in malaria endemic countries with $>10$ patients and follow up data available

\begin{tabular}{|c|c|c|c|c|c|c|}
\hline Study & Country & $\mathrm{N}$ patients & Type of treatment & Duration & Follow up & Outcome \\
\hline Pryor 1967 [49] & New Guinea & 99 & CLQ 1500 mg/3 days, then 300 mg/wk & NR & $\begin{array}{l}\text { average } 4.1 \mathrm{mths} \text { in hospital } \\
\text { plus } 6-23 \mathrm{mths} \text { out }\end{array}$ & $\begin{array}{l}\text { No change in spleen size, } \\
\text { general benefit }\end{array}$ \\
\hline Sagoe $1970[57]$ & Nigeria & 43 & PG 100 mg/day & $\geq 6$ mths & 6 mths & 32 improved 11 worsened \\
\hline Bagshawe 1970 [13] & Kenya & 28 & PG 100 mg/day & $1-26$ mths & $1-6$ mths & $\begin{array}{l}16 \text { improved } 11 \text { worsened } 8 \\
\text { unchanged }\end{array}$ \\
\hline Stuvier et al. 1971 [27] & India & 14 & PQ 15 days, then CLQ 300 mg/wk & 6-14 mths & once/mths for $\geq 6$ mths & $11 / 14$ spleen size $\downarrow 50 \%$ \\
\hline Stuvier et al. 1974 [71] & Uganda & 41 & CLQ 300 mg/wk or PG 100 mg/day & NR & 4- 20 mths & all improved \\
\hline Bryceson et al. 1976 [60] & North Nigeria & 30 & PG 100 mg/day & $3-12$ mths & 3 mths & 12/13 improved (17 lost) \\
\hline Fakunle and Greenwood 1980 [64] & Nigeria & 69 & PG 100 mg/day & 3 mths & 10 wks & 2 /40 died plus $8 / 29$ defaulters \\
\hline De Cock et al. 1986 [52] & Kenya & 38 & PG 100 mg/day or CLQ 300 mg/wk & NR & NR & 13/18 improved (20 lost) \\
\hline Crane 1986 [2] & Papua NG & 148 & CLQ 300 mg/wk & lifelong & 12-18 mths & 146 improved (2 lost) \\
\hline Gupta et al. 1987 [31] & India & 54 & CLQ $300 \mathrm{mg}, 1$ or 2/wk & $2 \mathrm{yrs}$ & $2 \mathrm{yrs}$ & 54 Improved \\
\hline Mac Onuigbo and Mbah 1992 [76] & Nigeria & 39 & PG 100 or $200 \mathrm{mg}$ & $2-12$ mths & $2-12$ mths & All improved (10 cured) \\
\hline Manenti et al. 1994 [79] & Tanzania & 312 & PMT 25 mg/wk & 1 mths & 3 mths & 208 improved 104 unchanged \\
\hline A-Elgayoum et al. 2011 [18] & Sudan & 54 & $\begin{array}{l}\text { Single short term treatment } \\
\text { (various regimens) }\end{array}$ & $1 \mathrm{~d}$ to 1 wk (often repeated) & $15-24$ mths & $\begin{array}{l}36 \text { improved } 12 \text { worsened } 6 \\
\text { unchanged }\end{array}$ \\
\hline Alkadarow et al. 2013 [69] & Sudan & 33 & CLQ 300 mg/wk & 3 mths & 3 mths & 14/21 improved (12 lost) \\
\hline
\end{tabular}

( $C L Q=$ chloroquine; $P G=$ proguanil; $P Q=$ primaquine; $P M T=$ pyrimethamine; $N R=$ not reported). 
Table 3 Treatment outcome: studies conducted in non endemic countries with $>10$ patients and follow up data available

\begin{tabular}{|c|c|c|c|c|c|c|}
\hline Study & Country & $\mathrm{N}$ patients & Treatment & Duration & Follow up & Outcome \\
\hline Van den Ende et al. 2000 [42] & Belgium & $\begin{array}{l}39 \text { Caucasians, } 17 \text { fully responding } \\
\text { to Fakunle criteria }\end{array}$ & $\begin{array}{l}\text { Single, short term treat for Pf } \\
\text { malaria (various regimens) }\end{array}$ & $\begin{array}{l}1 \text { day to } 1 \text { week according } \\
\text { to drug }\end{array}$ & $\geq 2$ wks (average 6 wks) & $\begin{array}{l}\text { All not re-exposed improved } \\
\text { or fully recovered }\end{array}$ \\
\hline Eseme et al. 2004 [43] & Italy & $\begin{array}{l}49 \text { Caucasians ( } 29 \text { fully responding } \\
\text { to Fakunle criteria) plus } 8 \text { Africans } \\
\text { (different countries) }\end{array}$ & $\begin{array}{l}\text { Single, short term treatment } \\
\text { for falciparum malaria } \\
\text { (various regimens) }\end{array}$ & 1- 4 days according to drug & 6-36 mths & $\begin{array}{l}\text { All not re-exposed improved } \\
\text { or fully recovered }\end{array}$ \\
\hline Puente et al. 2001 [83] & Spain & $\begin{array}{l}14 \text { Africans (13 from E. Guinea, } \\
1 \text { from Cameroon) }\end{array}$ & $\begin{array}{l}\text { Quinine standard dose for } \\
1 \text { wk then CLQ }\end{array}$ & 3- 9 mths (mean $=4.3$ mths) & $\begin{array}{l}3-9 \text { mths (mean }=4.3 \\
\text { mths) }\end{array}$ & $\begin{array}{l}\text { All not re-exposed improved } \\
\text { or fully recovered }\end{array}$ \\
\hline
\end{tabular}


weeks) showing improvement or a complete recovery. The Italian study (Table 3) [43] (57 patients, mostly European Caucasians, of which 28 with an incomplete 'early' stage HMS) confirmed the efficacy of short treatment in absence of re-exposure, and showed 100\% improvement at follow-up (six to 36 months after therapy). The remaining four papers are case reports. Two of them reported a global improvement at follow-up visits, two and 24 months after treatment, respectively $[17,82]$ : one used quinine plus doxycycline and the other one mefloquine. Conversely, one case was described with no improvement eight months after a three-day course of atovaquoneproguanil [46].

The prospective study in Spain (Table 3) [19], that was conducted on 14 African subjects, besides using a short course of anti-malarial treatment just as in the Belgian and Italian studies referred to above [42,43], also added weekly chloroquine for a longer period, ranging from three to nine months, basically obtaining the same clinical results (in those not re-exposed) as in the two previous studies. Most other authors opted for long-term treatment following, in some cases only, a short antimalarial course $[84,85]$. The duration of therapy varied from one [46] to 12 months or until recovery $[83,86]$. Intermittent therapy was also used, with quinine [45] or with chloroquine plus proguanil [87].

The most common prescription, just as in endemic countries, was chloroquine alone $[54,83,85,88]$, or in combination with doxycycline [46], with proguanil $[42,85,89]$ or with primaquine [90], or preceded by a short course of quinine $[19,83,88]$ or halofantrine [83]. Other regimens used for long-term treatment were proguanil $[67,85,86]$, mefloquine [91] or quinine plus doxycycline [17].

All patients with no further exposure and with available follow-up data improved. It is not clear whether a mere withdrawal of exposure, without treatment, could be sufficient to obtain HMS resolution: only a few case reports debate on this aspect. One described the persistence of HMS in a eight years old Caucasian boy, who had been on chloroquine prophylaxis while in Africa, after an 18-month stay in Europe [91]. Another case of HMS was diagnosed in an Ethiopian immigrant after a 19month stay in Israel [38]. On the contrary, a spontaneous resolution of the syndrome was reported in a Guinean patient after two months of residence in a malaria-free area, with a regression of the spleen size from $20 \mathrm{~cm}$ to $3-4 \mathrm{~cm}$ below the costal margin and a normalization of all laboratory findings [92]. The main results of the three case series described in Europe with more than ten patients are summarized in Table 3.

\section{Splenectomy}

Splenectomy in HMS is generally suggested for patients with huge splenomegaly and disabling symptoms, who do not respond to medical treatments [29,93]. One study analysing short- and long-term outcome of splenectomy reported a peri-operative mortality rate of about $31 \%$ rising to $39 \%$ at long-term (41-74 months) follow-up [94]. The most frequent peri-operative complications described were major bleeding and infections. The latter were the main cause of death in the following months. Most surviving patients improved. However, the liver tended to progressively enlarge, probably related to persistence of the antigenic stimulus [95]. In non-endemic areas, therapeutic splenectomy has been reported in Venezuela, Sri-Lanka, Hong Kong [30,39,41] and the USA (for haemolytic anaemia complicating HMS) [40].

\section{Discussion}

The literature available on HMS consists of some case reports and a few case series. Parameters considered by different authors are often heterogeneous and hardly comparable. However some key points are identifiable. First of all, HMS should be taken into consideration in all patients with splenomegaly living/having lived in malarious areas. Strict adherence to Fakunle's criteria is questionable. Some authors observed that cases not completely fulfilling the criteria can subsequently evolve into the full-blown, 'classical' HMS [42,43], thus representing an early stage of the syndrome. Considering the high fatality rate of this condition, if left untreated, as well as the wide availability of effective anti-malarial drugs, it seems appropriate to treat HMS even in case the classical triad of splenomegaly, raised IgM and antimalarial antibodies is only partially satisfied. Clearly, investigations of other possible causes of splenomegaly should be carried out, in particular, but not limited to, considering lymphoproliferative disorders.

The treatments administered have been heterogeneous and do not permit recommending a first choice regimen yet, considering the lack of randomized clinical trials. However, for patients who move from endemic to nonendemic areas, there is circumstantial evidence supporting the fact that an adequate short-course treatment is effective $[42,43]$. This contrasts with the more common choice of a long-term anti-malarial course in these cases, too, which is the classical approach that has been suggested and followed for decades. It reflects the view that the syndrome tends to evolve even though malaria parasites are no longer present in blood. This particular aspect was described in a study showing a progressive enlargement of the liver after splenectomy in a patient with negative thick blood films. This occurrence was attributed to persistence of the underlying stimulus to reticulo-endothelial system [95]. According to the most cited authors [2], the absence of parasitaemia is one of the diagnostic criteria. This view does not hold any longer. On the one hand, recent reports showed that more 
sensitive diagnostic tools have found a higher proportion of malarial infection in HMS patients [17]. This suggests that Plasmodium is present, albeit often at sub-microscopic parasite density. On the other hand, the full response to a short course of anti-malarial therapy indicates that the eradication of the infection is usually sufficient to cure HMS $[28,42,43]$. Therefore, the presence of Plasmodium in blood is necessary for a further development of the syndrome. This is also suggested by the unusual case of HMS reported above [67]: a child who still had circulating Plasmodium eight months after her last short-term visit to a malaria-endemic country.

\section{Conclusion}

Lifelong effective malaria prophylaxis or intermittent treatments are probably necessary for those who remain exposed to malaria transmission. Chloroquine seems to still be partially effective, even if $P$. falciparum resistance has developed. Possibly this regimen acts not only as an anti-malarial, but also as an immunomodulating and immunosuppressant therapy $[47,96]$, as it is suggested by the regression of the spleen size even in patients with lymphoproliferative disorders [60]. The choice of the drug should consider the local pattern of $P$. falciparum drug susceptibility, as well as the availability and cost of the different regimens. Splenectomy is potentially associated with high mortality, therefore it should be strictly limited to cases that do not respond to medical treatment $[94,97]$.

\section{Competing interests}

The authors declare that they have no competing interests.

\begin{abstract}
Authors' contributions
ZB conceived of the study, provided major contribution to the study design, revised critically the different versions of the draft manuscript, contributed to performing the systematic review, was in charge of the last version of the manuscript. SL contributed to the study design, performed the systematic review, wrote the first version of the manuscript. DB provided major contribution to the study design, performed the systematic review, revised critically the different versions of the draft manuscript. AA provided major contribution to the study design, revised critically the different versions of the draft manuscript. FG contributed to the study design, revised critically the different versions of the draft manuscript and contributed to the final version. All authors have given final approval of the version to be published and agree to be accountable for all aspects of the work in ensuring that questions related to the accuracy or integrity of any part of the work are appropriately investigated and resolved.
\end{abstract}

\section{Acknowledgements}

The authors, as well as the manuscript preparation, were funded by Sacro Cuore Hospital, Negrar, Verona. The funding body had no role in the study design, in the collection, analysis and interpretation of data, in the writing of the manuscript, and in the decision to submit the manuscript for publication.

\footnotetext{
Author details

'Centre for Tropical Diseases, S Cuore Hospital, 37024, Negrar Verona, Italy. ${ }^{2}$ Internal Medicine Department, Verona University, Piazzale L A Scuro, 10, 37134 Verona, Italy.
}

Received: 29 December 2014 Accepted: 14 April 2015

Published online: 29 April 2015

\section{References}

1. Bedu-Addo G, Bates I. Causes of massive tropical splenomegaly in Ghana. Lancet. 2002;360:449-54.

2. Crane G. Recent studies of hyperreactive malarious splenomegaly (tropical splenomegaly syndrome) in Papua New Guinea. P N G Med J. 1986;29:35-40.

3. Fakunle YM, Onyewotu II, Greenwood BM, Mohammed I, Holborow EJ. Cryoglobulinaemia and circulating immune complexes in tropical splenomegaly syndrome. Clin Exp Immunol. 1978;31:55-8.

4. Ziegler JL. Cryoglobulinaemia in tropical splenomegaly syndrome. Clin Exp Immunol. 1973;15:65-78.

5. Wells JV. Serum immunoglobulin levels in tropical splenomegaly syndrome in New Guinea. Clin Exp Immunol. 1968;3:943-51.

6. Wells JV. Immunological studies in tropical splenomegaly syndrome. Trans R Soc Trop Med Hyg. 1970;64:531-46.

7. Stuiver PC. [Tropical splenomegaly] (in Dutch). Tijdschr Gastroenterol. 1972;15:238-47.

8. Crane GG. The pathogenesis of tropical splenomegaly syndrome-the role of immune complexes. P N G Med J. 1977;20:6-13.

9. Bhatia K, Crane G. HLA and tropical splenomegaly syndrome in the Upper Watut Valley of Papua New Guinea. Hum Immunol. 1985;13:235-42.

10. Bhatia KK, Crane GG. HLA heterozygosity and hyperreactive malarious splenomegaly in the Upper Watut Valley of Papua New Guinea. P N G Med J. 1989;32:277-86.

11. Martin-Peprah R, Bates I, Bedu-Addo G, Kwiatkowski DP. Investigation of familial segregation of hyperreactive malarial splenomegaly in Kumasi, Ghana. Trans R Soc Trop Med Hyg. 2006;100:68-73.

12. Fakunle YM. Tropical splenomegaly. Part 1: Tropical Africa. Clin Haematol. 1981;10:963-75.

13. Bagshawe AF. Long-term proguanil therapy in idiopathic tropical splenomegaly. East Afr Med J. 1970;47:622-6.

14. Pryor DS. The mechanism of anaemia in tropical splenomegaly. Q J Med. 1967;36:337-56.

15. Ringelhann B, Miller H, Konotey-Ahulu Fl. The origin of anaemia in tropical splenomegaly syndrome. Acta Med Acad Sci Hung. 1973;30:331-41.

16. Torres JR, Villegas L, Perez H, Suarez L, Torres VMA, Campos M. Low-grade parasitaemias and cold agglutinins in patients with hyper-reactive malarious splenomegaly and acute haemolysis. Ann Trop Med Parasitol. 2003;97:125-30

17. Mothe B, Lopez-Contreras J, Torres OH, Munoz C, Domingo P, Gurgui M. A case of hyper-reactive malarial splenomegaly. The role of rapid antigen-detecting and PCR-based tests. Infection. 2008;36:167-9.

18. A-Elgayoum SME, El-Rayah EA, Giha HA. Validation of PCR for detection and characterization of parasitaemia in massive splenomegaly attributed clinically to malaria infection. Diagn Microbiol Infect Dis. 2011;70:207-12.

19. Puente S, Rubio JM, Subirats M, Lago M, Gonzalez-Lahoz J, Benito A. The use of PCR in the diagnosis of hyper-reactive malarial splenomegaly (HMS). Ann Trop Med Parasitol. 2000;94:559-63.

20. Crane GG, Wells JV, Hudson P. Tropical splenomegaly syndrome in New Guinea. I. Natural history. Trans R Soc Trop Med Hyg. 1972;66:724-32.

21. Bates I, Bedu-Addo G, Rutherford TR, Bevan DH. Circulating villous lymphocytes - a link between hyperreactive malarial splenomegaly and splenic lymphoma. Trans R Soc Trop Med Hyg. 1997;91:171-4.

22. Bates I, Bedu-Addo G, Bevan DH, Rutherford TR. Use of immunoglobulin gene rearrangements to show clonal lymphoproliferation in hyper-reactive malarial splenomegaly. Lancet. 1991;337:505-7.

23. Jimmy EO, Bedu-Addo G, Bates I, Bevan D, Rutherford TR. Immunoglobulin gene polymerase chain reaction to distinguish hyperreactive malarial splenomegaly from 'African' chronic lymphocytic leukaemia and splenic lymphoma. Trans R Soc Trop Med Hyg. 1996;90:37-9.

24. Wallace S, Bedu-Addo G, Rutherford TR, Bates I. Serological similarities between hyperreactive malarial splenomegaly and splenic lymphoma in West Africa. Trans R Soc Trop Med Hyg. 1998;92:463-7.

25. Bedu-Addo G, Rutheford T, Bevan D, Bates I. Splenic lymphoma with villous lymphocytes should be included in the differential diagnosis of massive splenomegaly. Croat Med J. 1998;39:412-8.

26. Verma S, Aggarwal A. Hyper-reactive malarial splenomegaly: rare cause of pyrexia of unknown origin. Indian J Pediatr. 2007;74:409-11.

27. Stuiver PC, Ziegler JL, Wood JB, Morrow RH, Hutt MS. Clinical trial of malaria prophylaxis in tropical splenomegaly syndrome. BMJ. 1971;1:426-9. 
28. Jaroensuk J, Stoesser N, Leimanis ML, Jittamala P, White NJ, Nosten FH, et al. Treatment of suspected hyper-reactive malarial splenomegaly (HMS) in pregnancy with mefloquine. Am J Trop Med Hyg. 2014;90:609-11.

29. Vriend WH, Hoffman SL, Silaban T, Zaini M. Splenectomy in massive tropical splenomegaly: two-to six-year follow-up in 14 patients. Trop Geogr Med. 1988;40:298-303

30. Nagaratnam N, De Silva DP, De Silva SP. Tropical splenomegaly syndrome in Ceylon. J Trop Med Hyg. 1973;76:80-2.

31. Gupta HL, Vankataswar N, Aggarwal A, Bhutani P. Tropical splenomegaly syndrome and the role of chloroquine prophylaxis. J Indian Med Assoc. 1987;85:298-300

32. Haider M, Nizami S, Qureshi A, Raza A, Mahar FK, Beg MA. Hyper-reactive malarial splenomegaly in the absence of raised IgM antibodies. Trop Doct. 2013;43:37-8.

33. Hoffman SL, Piessens WF, Ratiwayanto S, Hussein PR, Kurniawan L, Piessens PW, et al. Reduction of suppressor T lymphocytes in the tropical splenomegaly syndrome. N Engl J Med. 1984;310:337-41.

34. Torres RJ, Noya GO, Mondolfi GA, Peceno C, Botto AC. Hyperreactive malarial splenomegaly in Venezuela. Am J Trop Med Hyg. 1988;39:11-4.

35. Torres RJR, Magris M, Villegas L, Torres VMA, Dominguez G. Spur cell anaemia and acute haemolysis in patients with hyperreactive malarious splenomegaly. Experience in an isolated Yanomamo population of Venezuela. Acta Trop. 2000;77:257-62.

36. Alecrim WD, Alecrim MDG, Albuquerque BC, McNeill M, Dourado H, Prata A, et al. [Tropical splenomegaly in the Ituxi River, Amazonas, Brazil] (in Portuguese). Rev Inst Med Trop Sao Paulo. 1982;24:54-7.

37. Duarte MIS, Boulos M, Segurado AAC, Oliveira MS, Araujo ESA, Silva MA, et al. Hyperreactive malarious splenomegaly: Immunohistochemical demonstration of Plasmodium falciparum antigen in liver cells. Trans R Soc Trop Med Hyg. 1997;91:429-30.

38. Yermiyahu T, Maislos M, Shneider A, Ben Meir D, Lowenthal MN. Massive splenomegaly responsive to proguanil and with features of hairy cell leukaemia. Trans R Soc Trop Med Hyg. 1995;89:194-6.

39. Torres-Rojas JR, Rothschild H, Krotoski WA. Tropical splenomegaly syndrome in a nontropical setting. Am J Trop Med Hyg. 1981;30:1-4.

40. Ackerman L. Hyperreactive malarial syndrome. J Am Board Fam Pract. 1996;9:356-9.

41. Chim CS, Wong SS, Lam CC, Chan KW. Concurrent hyperreactive malarial splenomegaly and quartan malarial nephropathy - Plasmodium malariae revisited. Haematologica. 2004;89:ECR21.

42. Van Den Ende J, Van Gompel A, Van Den Enden E, Taelman H, Vanham G, Vervoort T. Hyperreactive malaria in expatriates returning from sub-Saharan Africa. Trop Med Int Health. 2000;5:607-11.

43. Eseme F, Lodesani C, Amicarelli E, Marocco S, Monteiro G, Anselmi M, et al. Hyperreactive malarial splenomegaly in Europeans. Giornale Italiano di Medicina Tropicale. 2004:9:61-4

44. Crane GG, Pryor DS. Malaria and the tropical splenomegaly syndrome in New Guinea. Trans R Soc Trop Med Hyg. 1971;65:315-24.

45. Garavelli PL. [Tropical splenomegaly. A case report] (in Italian). Recenti Prog Med. 2005;96:609.

46. Camara B, Kantambadouno JB, Martin-Blondel G, Berry A, Alvarez M, BenoitVical F, et al. Hyperreactive malarial splenomegaly: Three clinical cases and literature review. Med Mal Infect. 2009;39:29-35.

47. Dascalescu CM, Najman A. Tropical splenomegalies: Hyperreactive malarial splenomegaly and tropical splenic lymphoma with villous lymphocytes. Hématologie. 2005;11:259-63.

48. Lowenthal MN, Hutt MS, Jones IG, Mohelsky V, O'Riordan EC. Massive splenomegaly in Northern Zambia. I. Analysis of 344 cases. Trans R Soc Trop Med Hyg. 1980;74:91-8.

49. Pryor DS. Tropical splenomegaly in New Guinea. Q J Med. 1967;36:321-36.

50. Ouattara I, Ehui E, Tanon A, Eholie SP, Bissagnene E. [Hyperactive malarious splenomegaly: diagnosis and therapeutic problems in adults] (in French) Bull Soc Pathol Exot. 2008;101:295-7.

51. Kern P, Knobloch J, Riethmuller G, Dietrich M. Serological and immunological investigations in patients with gross splenomegaly from the Gabon. Tropenmed Parasitol. 1983;34:253-8.

52. De Cock KM, Hodgen AN, Jupp RA, Slavin B, Siongok TK, Rees PH, et al. Immunoglobin $\mathrm{M}$ and malarial antibody levels in hyper-reactive malarial splenomegaly. J Trop Med Hyg. 1986;89:119-21.

53. Gangneux JP, Vignes S, Poinsignon Y, Derouin F. Evolutive visceral malaria and hyperimmune palustral splenomegaly: a difficult distinction. Bull Soc Pathol Exot. 1999;92:27-8.
54. Rovere PA, Bisoffi Z. The hyperreactive malarial splenomegaly syndrome in Europeans: Is this more frequent than it appears? About three cases in Italian missionaries. Giornale di Malattie Infettive e Parassitarie. 1994;46:715-7.

55. Marsden PD, Crane GG. The tropical splenomegaly syndrome. A current appraisal. Rev Inst Med Trop Sao Paulo. 1976;18:54-70.

56. Manenti F, Porta E, Esposito R, Antinori S. Treatment of hyperreactive malarial splenomegaly syndrome. Lancet. 1994;343:1441-2.

57. Sagoe AS. Tropical splenomegaly syndrome: long-term proguanil therapy correlated with spleen size, serum IgM, and lymphocyte transformation. BMJ. 1970;3:378-82.

58. Crane GG, Pitney WR, Hobbs JR, Gunn C. Immunoglobulin levels in the Kaiapit and Upper Watut areas of New Guinea with special reference to the tropical splenomegaly syndrome. Trans R Soc Trop Med Hyg. 1971;65:795-807.

59. Greenwood BM, Groenendaal F, Bradley AK, Greenwood AM, Shenton F, Tulloch S, et al. Ethnic differences in the prevalence of splenomegaly and malaria in The Gambia. Ann Trop Med Parasitol. 1987;81:345-54.

60. Bryceson AD, Fleming AF, Edington GM. Splenomegaly in Northern Nigeria. Acta Trop. 1976;33:185-214.

61. De Cock KM, Hodgen AN, Lucas SB, Jupp RA, Slavin B, Arap Siongok TK, et al. Chronic splenomegaly in Nairobi, Kenya. I. Epidemiology, malarial antibody and immunoglobulin levels. Trans R Soc Trop Med Hyg. 1987:81:100-6.

62. Allam MM, Alkadarou TA, Ahmed BG, Elkhair IS, Alansary EH, Ibrahim ME, et al. Hyper-reactive Malarial Splenomegaly (HMS) in malaria endemic area in Eastern Sudan. Acta Trop. 2008;105:196-9.

63. Jones IG, Lowenthal MN. Fulminant tropical splenomegaly syndrome. Med J Aust. 1975:2:645-7.

64. Fakunle YM, Greenwood BM. Mortality in tropical splenomegaly syndrome. Trans R Soc Trop Med Hyg. 1980;74:419.

65. Lowenthal MN, Hutt MS. Tropical splenomegaly syndrome in a caucasian in Africa. BMJ. 1970:3:262-3.

66. De Franceschi L, Sada S, Andreoli A, Angheben A, Marocco S, Bisoffi Z. Sickle cell disease and hyperreactive malarial splenomegaly (HMS) in young immigrants from Africa. Blood. 2005;106:4415-7.

67. Ladhani S, Dosekun E, Patel V, Shingadia D. Massive hepatosplenomegaly in a child with malaria. Pediatr Infect Dis J. 2002;21:1090-2.

68. Crane GG, Rowley MJ, Warburton MF, Mackay IR. Humoral immune responses in the tropical-splenomegaly syndrome in New Guinea. Clin Sci. 1972:43:869-79.

69. Alkadarou T, Musa A, Alkadarou A, Mahfouz MS, Troye-Blomberg M, Elhassan AM, et al. Immunological characteristics of hyperreactive malarial splenomegaly syndrome in sudanese patients. J Trop Med. 2013:961051. doi:10.1155/2013/961051

70. De Morais JA. [Macroglobulinemic splenomegaly of Charmot or tropical splenomegaly syndrome: report of the 1st case diagnosed in Angola and review of the world literature] (in Portuguese). An Inst Hig Med Trop (Lisb). 1977;5:293-323.

71. Stuiver PC, Buttner DW, Mannweiler E. Immunodiagnostic studies in tropical splenomegaly syndrome in Uganda. Trop Geogr Med. 1974;26:121-5.

72. Adekile AD, Adeodu OO, Jeje AA, Odesanmi WO. Persistent gross splenomegaly in Nigerian patients with sickle cell anaemia: relationship to malaria. Ann Trop Paediatr. 1988;8:103-7.

73. Fakunle YM, Greenwood BM, Fleming AF, Danon F. Tropical splenomegaly syndrome or chronic lymphatic leukaemia? Trop Geogr Med. 1979;31:353-8.

74. Khan MK, Kamruzzaman M, Quddus MR. Hyperreactive malarial splenomegaly (HMS). Mymensingh Med J. 2006;15:204-7.

75. Lowenthal MN. Tropical splenomegaly syndrome. Med J Zambia. 1982;16:14-5.

76. Onuigbo MA, Mbah AU. Tropical splenomegaly syndrome in Nigerian adults. West Afr J Med. 1992;11:72-8.

77. Ree GH. Tropical splenomegaly. Trans R Soc Trop Med Hyg. 1976;70:259.

78. David-West AS. Relapses after withdrawal of proguanil treatment in tropical splenomegaly syndrome. BMJ. 1974;3:499-501.

79. Crane GG, Hudson P, Hudson BET. The effect of suppressive antimalarial therapy in tropical splenomegaly syndrome in New Guineans. P N G Med J. 1973;16:46-50

80. Ssebabi EC, Jagwe JG, Nzaro E, Amsel S. Tropical splenomegaly syndrome: an immune complex disease. East Afr Med J. 1975;52:680-5.

81. Tobena Rue M, Coll Usandizaga F, Moraga Llop FA, Toran Fuentes N, Garcia Pena MP. [Hyper-reactive malarial splenomegaly in a 9 year-old Equatorial Guinean child] (in Spanish). An Pediatr (Barc). 2011;75:80-1.

82. De laco G, Saleri N, Perandin F, Gulletta M, Ravizzola G, Manca N, et al. Hyper-reactive malarial splenomegaly in a patient with human immunodeficiency virus. Am J Trop Med Hyg. 2008;78:239-40. 
83. Puente S, Subirats M, Benito A, Rubio JM, Gonzalez-Lahoz JM. Hyperreactive malarial splenomegaly in Europeans: Report of five cases. J Travel Med. 2001;8:322-4.

84. Granier H, Vatan R, Nicolas X, Richecoeur M, Martin J. [Hyperreactive malarial splenomegaly in a European returning from Africa] (in French). Rev Med Interne. 1999;20:431-3.

85. Moraes MF, Soares M, Arroz MJ, Do Rosario VE, Pimenta DA Graca J, Abecasis P. [New concepts in hyperreactive malarial splenomegaly] (in Portuguese). Acta Medica Portuguesa. 2003;16:41-6.

86. Bhattacharya DN, Harries JR, Emerson PA. Tropical splenomegaly syndrome (T.S.S.) in a European. Trans R Soc Trop Med Hyg. 1983;77:221-2.

87. Dascalescu CM, Rosenzwajg M, Bonte H, Mir IA, Aoudjhane M, Smadja NV, et al. BCl-2 and immunoglobulin gene rearrangements in patients with malaria related chronic splenomegaly. Leuk Lymphoma. 2004;45:2093-7.

88. Chagnon A, Talard P, De Jaureguiberny JP, Mafart B, Pierre C, Carli P. [Hyper-reactive malarial splenomegaly in an European returning from Central Africa] (in French). Presse médicale. 1989;18:938

89. Orus J, Martinez A, Corachan M, Valls ME. Hyperreactive malarial splenomegaly syndrome in a European patient. Trop Doct. 1996;26:140-1.

90. Evans DI, Reddy PM, Wolman B. Tropical splenomegaly, sickle-cell trait, and P. falciparum infection. Br Med J. 1972;1:250-1.

91. Van Den Ende J, Van Gompel A, Van Den Enden E, Colebunders R. Development of hyperreactive malarious splenomegaly in an 8-year-old caucasian boy, 18 months after residence in Africa. Ann Soc Belg Med Trop. 1994;74:69-73

92. Vila N, Pallares L, Sierra C, Estruch R. Hyperreactive malarial splenomegaly. Medicina Clínica. 1993;100:75.

93. Ajao OG. Enlarged spleen syndrome. J Natl Med Assoc. 1980;72:323-5.

94. Crane GG, Pryor DS, Wells JV. Tropical splenomegaly syndrome in New Guinea. II. Long term results of splenectomy. Trans R Soc Trop Med Hyg. 1972;66:733-42.

95. Hamilton PJ, Stuiver PC, Ziegler JL. Splenectomy in tropical splenomegaly syndrome-a five year follow-up. J Trop Med Hyg. 1971;74:230-2.

96. Betticher DC, Nicole A, Pugin P, Regamey C. The hyperreactive malaria splenomegaly syndrome in a European: Has the treatment a modulatory effect on the immune system? J Infect Dis. 1990;161:157-9.

97. Pryor DS. Splenectomy in tropical splenomegaly. BMJ. 1967:3:825-8.

\section{Submit your next manuscript to BioMed Central and take full advantage of:}

- Convenient online submission

- Thorough peer review

- No space constraints or color figure charges

- Immediate publication on acceptance

- Inclusion in PubMed, CAS, Scopus and Google Scholar

- Research which is freely available for redistribution 